\author{
Marcin Pawlak \\ University of Szczecin \\ e-mail: marcin.pawlak@usz.edu.pl
}

\title{
MONTE CARLO VALUATION OF THE OPTION TO EXPAND WITH APPLICATION IN MULTI-STOREY CAR PARKING
}

\section{ZASTOSOWANIE DWUKROTNEJ SYMULACJI MONTE CARLO DO WYCENY OPCJI ROZSZERZENIA INWESTYCJI NA PRZYKLADZIE WIELOPOZIOMOWEGO PARKINGU}

DOI: $10.15611 /$ pn.2017.482.17

JEL Classification: G17, G32, D81

Summary: The aim of this paper is to present the application of Double Monte Carlo Simulation (2MC) in the valuation of investments containing the growth option. Paper presents a procedure for constructing a valuation model along with methods of identifying input and key-decision variables. Presented methodology is applied to valuation of expansion option in a multi-storey car park at Bluewater mall. Paper finishes with an interpretation of the valuation results and is summarized with conclusions on used methodology.

Keywords: Real Options, Monte Carlo Simulation, project valuation.

Streszczenie: Celem artykułu jest zastosowanie dwukrotnej symulacji Monte Carlo (2MC) w ocenie efektywności projektów inwestycyjnych zawierających opcję wzrostu. Pierwszą część stanowi opis metodyki uzupełniony procedurą budowy modelu wyceny wraz ze sposobami identyfikacji parametrów wejściowych i decyzyjnych. W drugiej części opisana jest wycena opcji rozszerzenia na przykładzie wielopoziomowego parkingu w centrum handlowym w Bluewater. Podsumowaniem artykułu jest interpretacja otrzymanych wyników oraz wnioski końcowe.

Słowa kluczowe: opcje realne, symulacja Monte Carlo, ocena efektywności inwestycji.

\section{Double Monte Carlo Simulation as a method of real option valuation}

Double Monte Carlo Simulation is a method of valuation of real options [Wiśniewski 2005, 2006] which is based on the approach proposed by Copeland and Antikarov 
[2001] to resolve the problem of many uncertainty factors influencing the project. In the method proposed by T. Wiśniewski first simulation is used to calculate consolidate project volatility and second one to estimate the real option value. The essence of the method is to simulate the expected value of the project in two models - base model of the project without option and extended model which allows calculating investments value with option. Mean difference between projects values determines the value of the real option.

To apply double Monte Carlo simulations, the following procedure is used:

- forecast of the main risk parameters (e.g. demand) and calculation of their distribution (including basic parameters, such as the mean, minimum, and standard deviation);

- construction of a base model of NPV, taking into account project assumptions;

- construction of extended NPV model (based on the base model) with conditions and formulas for the option execution;

- Monte Carlo simulation of both models;

- comparison of the distributions resulting from simulations (the model with the option and without option), in order to calculate the option value;

- the analysis of the results.

\section{Monte Carlo Valuation of the Option to Expand with Application in Multi-Storey Car Parking}

One of the most common uses of real options, often mentioned in the literature [e.g. Bulan et al. 2006; Kyungwon 2008] is investing in real estate. On the basis of investment in multi-storey car parking at Bluewater shopping centre (http://www. bluewater.co.uk) in the UK, described in R. Neufville's, S. Scholtes's and T. Wang's [2006] paper we conducted an example valuation of expansion option by Double Monte Carlo Simulation (2MC). The data of the reference paper has been modified to show the specificity of the method.

The analysed investment is the expansion of Bluewater shopping centre with additional parking spaces. Investors can choose one of two projects to build multistorey car park. The first one involves the construction of 6 floors (including two underground levels). The second project involves the strengthening of the originally planned structure (six floor garage) with possibility to build two more floors (up to eight levels). The construction cost of each subsequent floor above the ground is $10 \%$ higher than the cost of the floor situated below. Higher costs are the result of technical difficulties associated with the higher construction and the use of additional equipment. Each level consists of 200 parking spaces. After completion of construction works (six floors) the whole building will have 1,200 parking spaces.

Common assumptions in the base and investments are:

- the cost of construction of the single parking space is set at 8000 pounds, with a $10 \%$ increase for every level above the underground level; 
- the average annual income for each used parking space is 6,000 pounds;

- the average annual operating cost of a single parking space is 1,000 pounds;

- annual ground lease costs of 1.8 million pounds is payable at the beginning of each year;

- cost of capital used in discounting is $9 \%$;

- the demand equals the number of used parking spaces (the only limitation is the size of the parking);

- the duration of the investment is 20 years, after this period, the building will be sold.

For sake of simplicity we assume that only one risk factor affects the value of both projects. This factor is the demand for parking spaces at the mall. Demand at the starting point of the investment amounts to 750 parking spaces and forecast assumes that for the first 10 years demand will grow by an average of 75 parking places per year and then will stabilize. Annual volatility of real demand compared to the forecast amounts to $15 \%$, while assuming its minimum value at a distance of three sigma from the forecast mean 1.

The project extension - option execution is dependent on the size of real demand and it involves the construction of one or two floors (with the restriction that the building can have only 8 floors). The necessary condition that enables the expansion of car parking is to strengthen the original six-floor structure, which will increase the construction costs of the parking prepared for extension by 5\%. Managers in the planning stage, based on demand forecasts will have to decide whether more favourable is to strengthen the construction and enable car parking extension in the future or to implement only the base investment.

Based on management experience the practical formula for the decision to expand the parking for one floor is situation when real demand will exceed the capacity of the multilevel parking two years in a row. When it happens again then another floor will be build. The lifetime of the option due to the assumptions will amount to 13 years (from $3^{\text {rd }}$ year till $15^{\text {th }}$ ). Last time when option may be exercised is five years before the end of the project. The expansion will decrease the maintenance costs of parking spaces by $10 \%$ after the first extension, and by another $10 \%$ after the second one. At the end of both projects (base and expanded) investment will be sold. The basic assumptions of the valuation are summarized in Table 1.

The first stage in valuation of the described investment was to determine key variable(s) which influences the project value, for example it can be demand, prices, costs, etc. Second was to find a parameter which determines whether the option is exercised or not. For multi-level garage at the Bluewater mall one risk factor

${ }^{1}$ So-called three-sigma rule states that in normal distribution nearly all values are taken to lie within three standard deviations of the mean, i.e. that it is empirically useful to treat $99.7 \%$ probability as a near certainty. In this case, the application of this rule is to determine the lower limit of the distribution of demand which limits the ability to draw negative numbers. 
Table 1. Basic assumptions of the valuation

\begin{tabular}{|c|c|}
\hline Base project assumptions & Expanded project assumptions \\
\hline Project time $=20 \mathrm{y}$. & Project time $=20 \mathrm{y}$. \\
\hline No expansion possible & Expansion possibility in y. 3-15 \\
\hline $\mathrm{I}_{0}=11,4$ million $£$ & $\begin{array}{l}\mathrm{I}=11,4 * 1,05=11,9 \text { million } £ \\
\mathrm{I}^{0}=2,6 \text { million } £-\text { year. } 3-15 \\
\mathrm{I}_{2}^{1}=2,8 \text { million } £-\text { year of } \mathrm{I}_{1}-15 \mathrm{y} .\end{array}$ \\
\hline $\begin{array}{l}\text { Demand } y_{0}=750 \\
\text { Average demand grow in y. } 1-10=75 \\
\text { Average demand grow in y. } 11-20=0 \\
\text { Volatility }=15 \%\end{array}$ & $\begin{array}{l}\text { Demand } y_{0}=750 \\
\text { Average demand grow in y. } 1-10=75 \\
\text { Average demand grow in y. } 11-20=0 \\
\text { Volatility }=15 \%\end{array}$ \\
\hline 6 floors $=1200$ parking spaces & $\begin{array}{l}6 \text { floors }=1200 \text { parking spaces } \\
\text { After I } 7 \text { floors }=1400 \text { spaces } \\
\text { After } I_{2}^{1} 8 \text { floors }=1600 \text { spaces }\end{array}$ \\
\hline Avg. revenue/space $=6000 £$ & Avg. revenue/space $=6000 £$ \\
\hline Cost of lease $=1,8$ million $£$ & Cost of lease $=1,8$ million $£$ \\
\hline Operating cost $/$ space $=1000 £$ & $\begin{array}{l}\text { Operating cost } / \text { space }=1000 £ \\
\text { After } I_{1}=900 £ / \text { space } \\
\text { After } I_{2}=800 £ / \text { space }\end{array}$ \\
\hline
\end{tabular}

Source: own study.

Table 2. An example of the analysis of condition for option execution

\begin{tabular}{|c|c|c|c|c|c|c|}
\hline Year & $\begin{array}{c}\text { Forecast } \\
\text { of demand } \\
\text { (trend) }\end{array}$ & $\begin{array}{c}\text { Minimal } \\
\text { forecasted } \\
\text { demand }\end{array}$ & $\begin{array}{c}\text { Parking } \\
\text { capacity }\end{array}$ & $\begin{array}{c}\text { Simulated } \\
\text { demand } \\
\text { (exemplary } \\
\text { iteration) }\end{array}$ & $\begin{array}{c}\text { Simulated } \\
\text { demand } \\
\text { > parking } \\
\text { capacity }\end{array}$ & $\begin{array}{c}\text { Option } \\
\text { execution }\end{array}$ \\
\hline 0 & 750 & 0 & 1200 & 750 & No & \\
\hline 1 & 825 & 456 & 1200 & 768 & No & \\
\hline 2 & 900 & 495 & 1200 & 1024 & No & \\
\hline 3 & 975 & 537 & 1200 & 1229 & Yes & \\
\hline 4 & 1050 & 579 & 1200 & 1308 & Yes & \\
\hline 5 & 1125 & 621 & 1200 & 1200 & No & Execution \\
\hline 6 & 1200 & 660 & 1400 & 1134 & No & \\
\hline$(\ldots)$ & $(\ldots)$ & $(\ldots)$ & $(\ldots)$ & $(\ldots)$ & $(\ldots)$ & \\
\hline 10 & 1500 & 825 & 1400 & 1598 & Yes & \\
\hline 11 & 1500 & 867 & 1400 & 1590 & Yes & \\
\hline 12 & 1500 & 909 & 1400 & 1676 & Yes & Execution \\
\hline 13 & 1500 & 951 & 1600 & 1809 & Yes & \\
\hline$(\ldots)$ & $(\ldots)$ & $(\ldots)$ & $(\ldots)$ & $(\ldots)$ & $(\ldots)$ & \\
\hline 20 & 1500 & 1239 & 1600 & 1675 & Yes & \\
\hline
\end{tabular}

Source: own study. 
was determined, i.e. the demand. Stochastic distribution of demand and drawn in the simulation directly affect the value of the project and the potential decisions of managers. Demand forecast, the parameters of distribution and analysis of its impact on the project are presented in Table 2.

We assumed that the demand has normal distribution with the mean in the form of demand projections and a maximum distance of 3 standard deviations from the mean. There is also a strong autocorrelation of demand during the project $(0.8)$.

The drawn variables are used in the subsequent financial model iterations. For each decision variable, it is necessary to specify the conditions under which it would be possible to exercise the option. In the considered case, the demand is limited by the minimum forecasted demand (see Table 2 and Figure 1) and the option exercise depends on the capacity of car parking. In every single iteration of the simulation model, when the demand in the two subsequent years exceeds the number of parking spaces, the construction of one of the two additional floors will start. The moments when option was exercised for single simulation iteration in extended model are marked in grey (see Table 2).

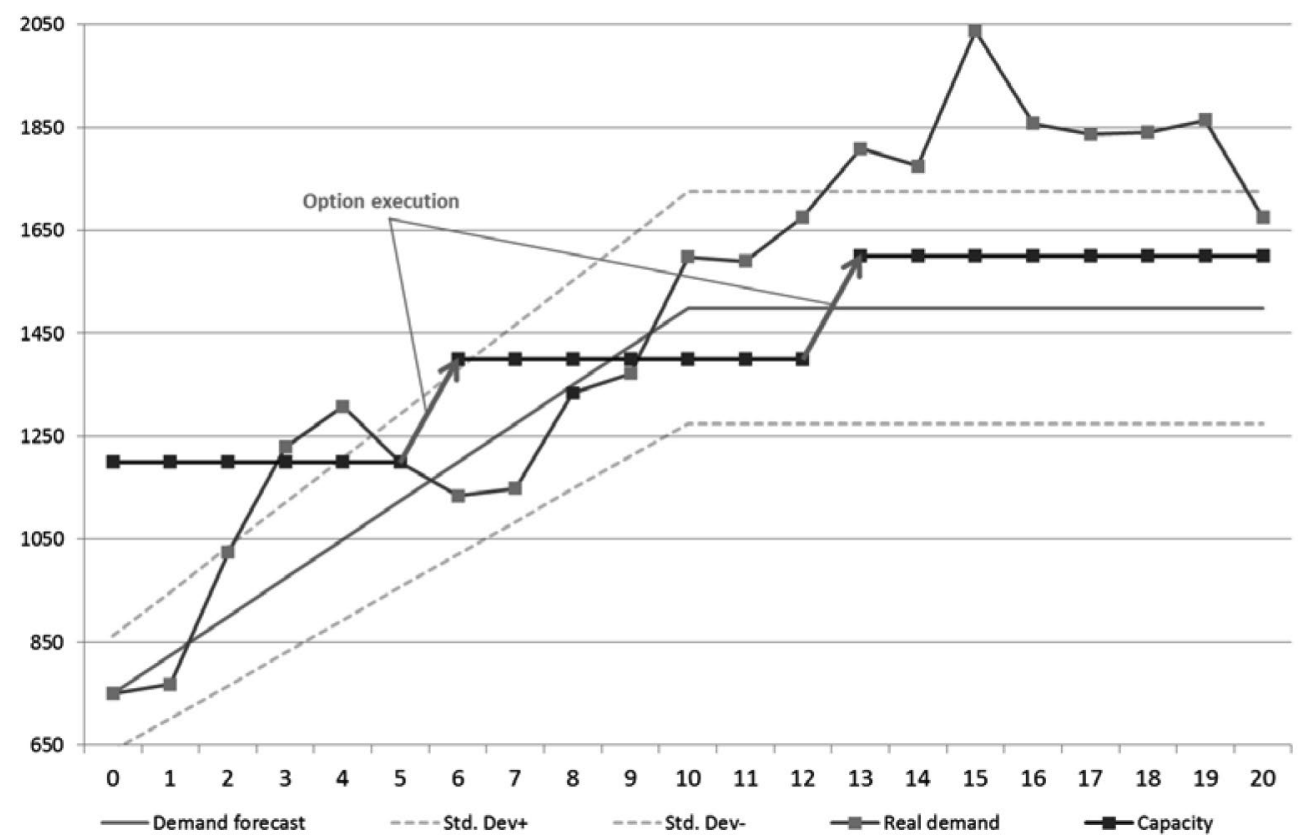

Fig. 1. An example of a decision variable and its impact on option execution (based on Table 2)

Source: own study.

The value of the investment project depends on many factors such as price, demand, unit production costs, etc. Managers are forced to analyse the impact of 
these factors to make the right decisions and maximize the expected value of future cash flows. More complex and dynamic investment environment, however, often forces the abandonment of a detailed analysis of all parameters and focus on the key factor that have the greatest impact on the ongoing project.

To assess investment effectiveness using simulation methods we need to identify risk factors (usually several factors), and describe them stochastically. The simulations' results are dependent on the variables and can be also described stochastically. To effectively manage the investment project on the base of these parameters we have to choose (usually subjectively) these which have biggest impact on the project's value and also which can be easily observed and analysed. Therefore, we have, in many cases strategic decisions and also option exercise dependent on one variable or several independent or related factors (e.g. dependent on the function of demand and prices). For each decision variable, the boundary conditions are set, beyond which the reaction takes place as it is presented in Figure 1.

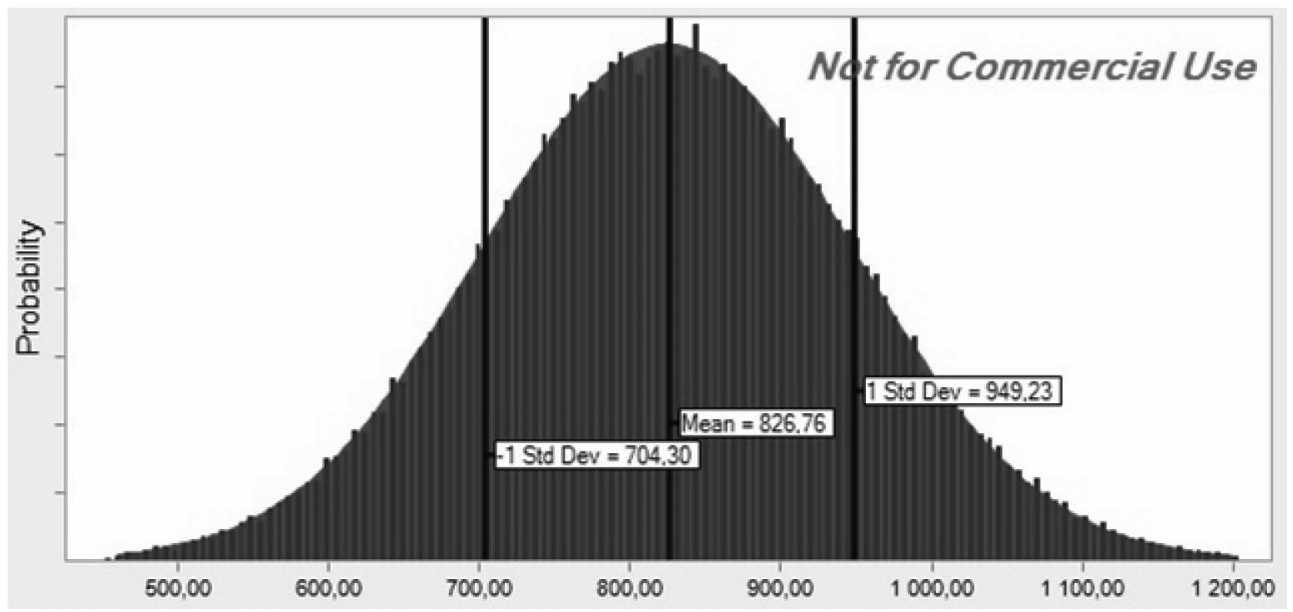

Fig. 2. Projected and simulated distribution of the demand in the first year of investment Source: own study.

After determining the decision variable (or several variables) for the project it is necessary to determine the distribution (selecting the appropriate density function) for all variables in the model. This is very important because the quality of the output data depends on the precision of parameters which determines projects value. Depending on the described parameters and the available information, forecasts, etc., we can select the appropriate stochastic distribution. In practice, most widely used is the normal distribution (e.g. to describe inflation or future prices), log-normal (for the value of real estate, stock prices, inventory), triangular (e.g. in estimating sales or marketing costs), discrete (e.g. for fixed depreciation) or Bernoulli distribution. 
Proper determination of the distribution parameters, such as the expected value, standard deviation, minimum or maximum, has the greatest impact on the result. The figure below shows the expected (full colour) and drawn (bars) distribution of the demand in the first year of investment.

When there is a need to match the variable characteristic with a stochastic distribution, earlier-created forecasts, often based on historical data, expert knowledge or comparison with similarly behaved parameters, can be helpful. Good model which is a comprehensive representation of reality should be complemented by links between various variables (correlation and autocorrelation). Each year of the project life, based on the demand forecasts (mean, standard deviation, minimum) was matched with a proper distribution - in this case a normal distribution, enabling the simulation of the variable.

The next step in the valuation was the construction of the classical model of NPV. Based on the projected demand (taking into consideration limited capacity of the car parking), estimated revenues and expenses, it was possible to calculate cash flow values and then the NPV of the base project. If the forecasts for demand would be exactly like demand forecast, the NPV would amount to 12.4 million pounds.

The most difficult step in the real option valuation using Double Monte Carlo simulation is the construction of the extended NPV model. The difficulties are connected with implementing all costs of obtaining and maintenance of the options in the model. The model should be also prepared to automatically exercise (or not exercise) the option in any single iteration. The decision about option execution should be made based on the chosen variable (or variables) and should be associated with the specifics of the project characteristics' changes. For the option to expand in the multilevel garage there would be an investment increase, more available parking spaces, operating cost per space decrease, etc.

Based on the sample projected demand (see Table 2) the option is exercised in years 9 and 10, resulting in an increase in revenues, depreciation and working capital and the decrease in unit variable costs. This translates into a higher NPV than in the static model (14.5 million pounds). Comparing the static model and a model with the option, and assuming that the demand forecasts come true, we receive the real option value of 2.1 million pounds. So, if the forecast meets reality it is worth to have an opportunity to expand the car parking. When market conditions are unfavourable, when the demand for parking spaces will be smaller than the capacity of car parking, the option will be not executed. There is also a possibility that only one additional floor would be build.

Before the start of the investment, managers know the forecast and they need to decide whether to invest 0.57 million pounds to prepare the building for expansion or not.

To solve this problem, we conducted a simulation on two models (extended and the base). After 200,000 iterations (of the static and also extended model) we 
received NPV and extended NPV distributions, as shown in the chart (see Figure 3). The extended NPV contains a value of static NPV and value of the real option.

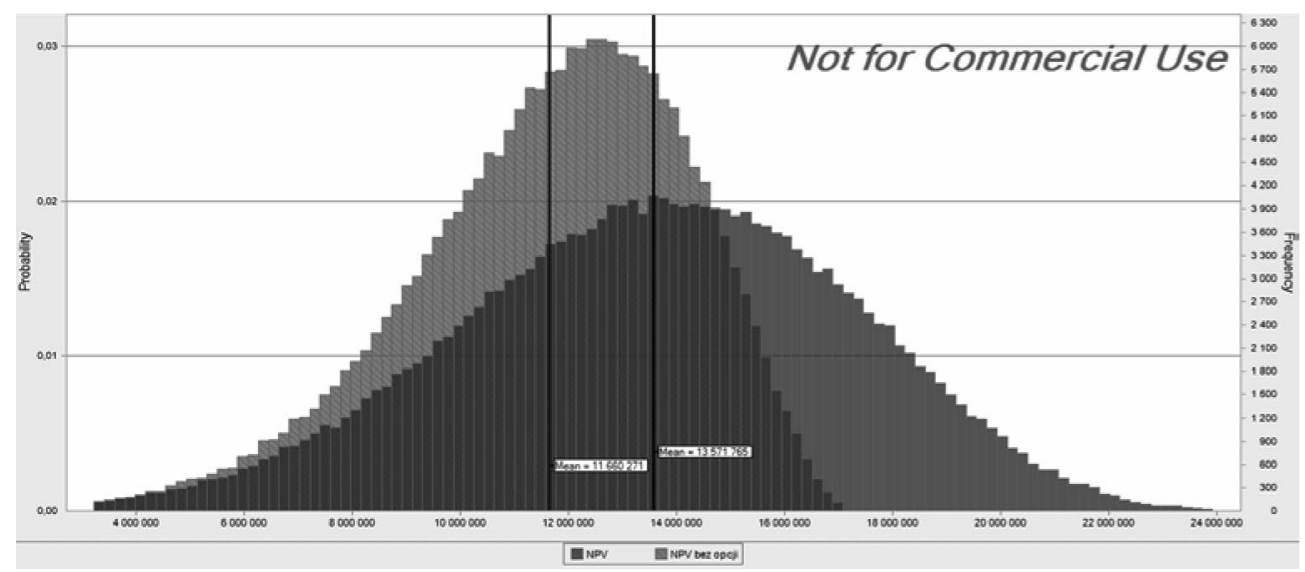

Fig. 3. Comparison of implied simulation distributions with and without the option Source: own study using Crystal Ball.

The figure above shows that the value of the extended project is shifted to the right (both the mean and the median), which proves its higher expected value compared to base investment.

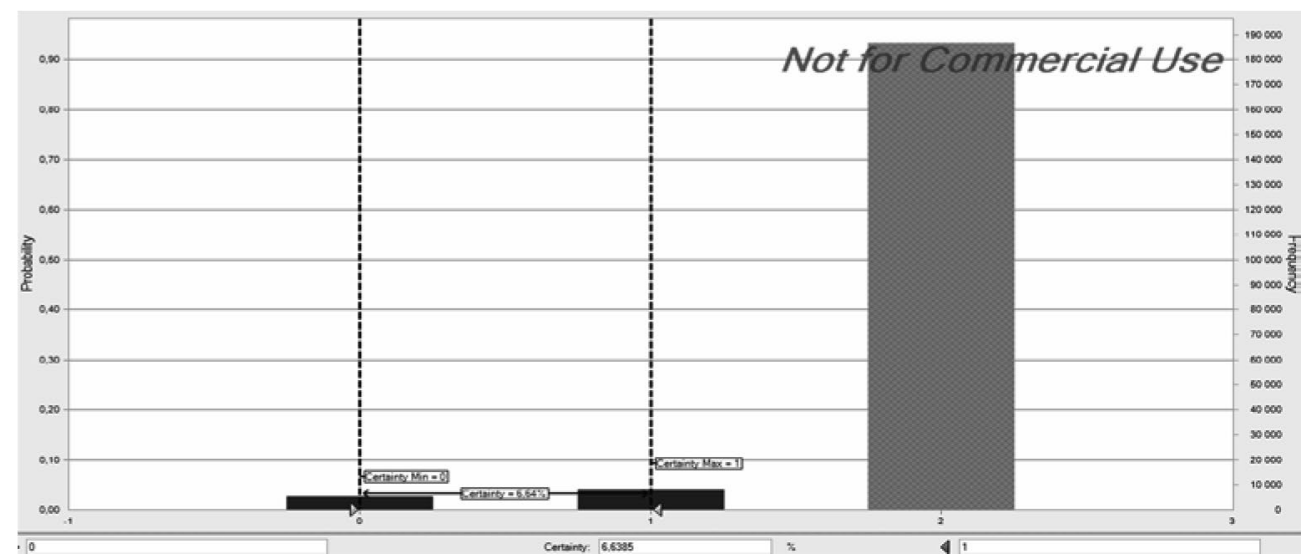

Fig. 4. Exercise of options in the extended simulation model

Source: own study using Crystal Ball.

In the simulations carried out, the option was executed almost always (97.3\%), including single exercise at $4.1 \%$. This could be explained by the higher than 
forecasted demand for parking spaces, which favoured the construction of two additional floors. Comparing the average values of received distributions (see Table 3), we can determine the value of the option to expand.

Table 3. Parameters of implied distributions

\begin{tabular}{|l|c|c|c|}
\hline \multicolumn{1}{|c|}{ Specification } & $\begin{array}{c}\text { Base model } \\
\text { (NPV) }\end{array}$ & $\begin{array}{c}\text { Extended model } \\
(\mathrm{NPV}+\mathrm{ROV})\end{array}$ & ROV \\
\hline Forecasted static demand & 12.4 & 14.5 & 2.1 \\
\hline Mean & $\mathbf{1 1 . 7}$ & $\mathbf{1 3 . 6}$ & $\mathbf{1 . 9}$ \\
\hline Median & 12.0 & 13.7 & 2.0 \\
\hline Standard deviation & 2.6 & 3.7 & 1.7 \\
\hline Skewness & -0.65 & -0.25 & 0.06 \\
\hline Kurtosis & 2.96 & 2.93 & 2.44 \\
\hline Coefficient of variation & $22.1 \%$ & $27.2 \%$ & $89.1 \%$ \\
\hline Minimum & -1.7 & -2.4 & -3.1 \\
\hline Maximum & 16.9 & 25.0 & 8.2 \\
\hline
\end{tabular}

Source: own study using Crystal Ball.

To determine the expected value of the real option contained in the analysed project we should subtract the 11.7 million pounds of the base model from the average value of the expanded project (13.6 million pounds). The result is 1.9 million pounds, which means that in this situation we should invest in strengthening the initial design just to be able to react to a possible increase in demand through the expansion of multi-storey car parking. The value of the option can also be read from the following illustration (see Figure 5).

The characteristic for the figure presenting the distribution of the expansion option are the slender bars (visible on the left side) showing these points or small ranges of values where value is cumulated (high probability of occurrence) concerning the terms of the option exercise. When they are restrictive, they impede the development of the car parking with another floor and cause a build-up of the model results before the exercise of options. Forecasts for demand assumed its gradual increase, and if it exceeded two years in a row the number of available parking spaces then is followed by option exercise.

The simulation result show, however, many cases in which the predetermined condition is satisfied partially (one extension $-4.1 \%$ of iterations) or was not satisfied at all (no extensions $-2.7 \%$ of iterations). The generated demand was not fully implemented repeatedly and the proceeds were restricted by the maximum number of parking spaces. For this reason, on the left side of the figure we can see specific stairs and peaks. Another interesting observation is a peak on the right side of the chart. It is an accumulation of situations when the option is not exercised 


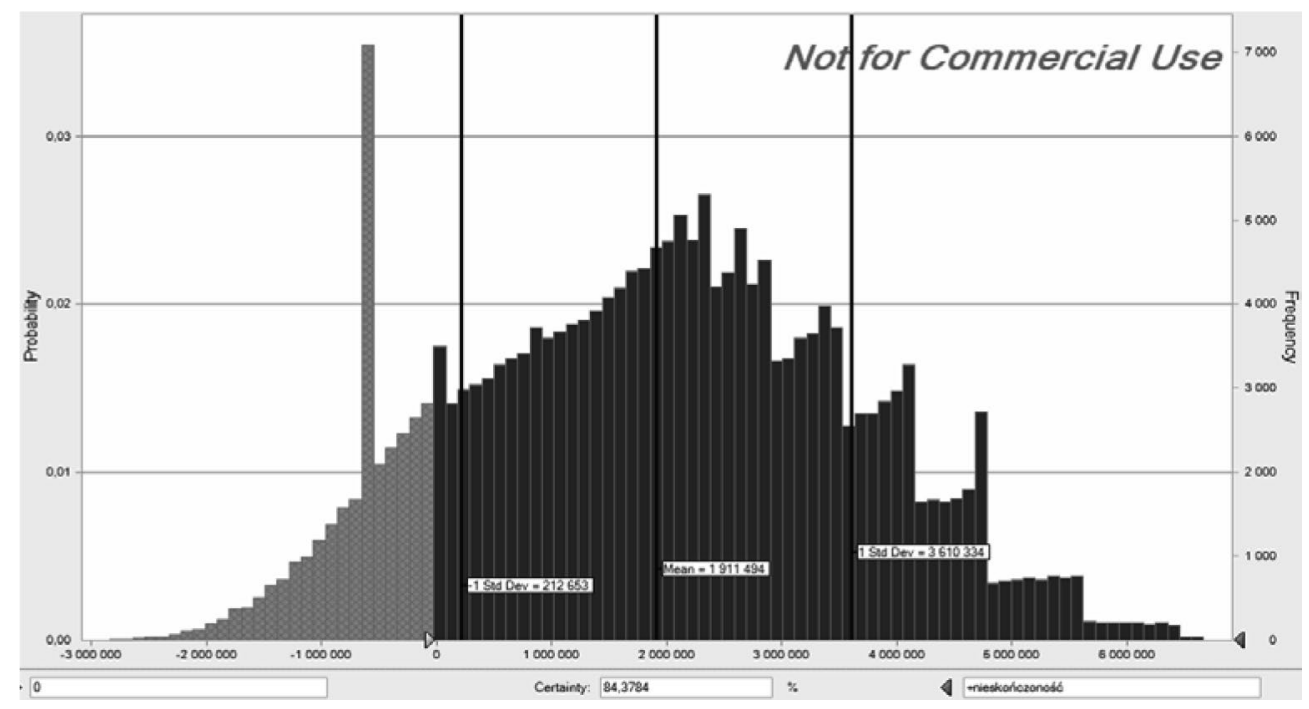

Fig. 5. Distribution of the real option value

Source: own study using Crystal Ball.

( $2.7 \%$ of iterations) and the additional value of investment (option is created by additional investment cost -0.5 million pounds) is pulling value of the option down. On the basis of the obtained results it can be stated that the expanded project should be implemented, as in most cases $(84.4 \%)$ it would generate a higher value.

\section{Conclusion}

The theory of real options is still in the initial phase of development. There is a number of drawbacks of the real option theory, especially in the area of assumptions and valuation methods. One of the very basic assumptions which is not met in reality is the assumption that one can observe gross value of the project and, on that basis, decide to execute the real option in a deterministic way in the preselected moment (or moments) in the future. The proposed method of the real option valuation relaxes this assumption and allows making an option execution decision which is based on the value of the proxy variable. The selected proxy variable is much easier to observe and to select the right triggering value for the option execution. Moreover, the method avoids the problem of selecting the right form of stochastic process which one should use to describe the changes in the project value.

A combination of many risk factors and its parameters allows calculating project's volatility making it more easily to observe and include in the model. Another advantage of the $2 \mathrm{MC}$ is the possibility to create model which could accurately describe even unique investment and its environment taking into account 
also complicated option (or more than one option) execution conditions. In the presented valuation example, it is very important to calculate precisely the values of parameters and connections between them, because the prediction errors could have huge influence on the result. Also, to avoid misleading results, the condition of option execution should be as accurate as possible to a real decision situation. The results obtained by this method show a comprehensive view of the project risk and give an investment decision recommendation based on probability. Also, the amount of information about the option value, probability of option execution and other characteristics (e.g. wrongly executed options or moment of execution) is greater than in other methods used in ROV.

\section{References}

Bulan L., Mayer Ch., Somerville C.T., 2006, Irreversible Investment, Real Options, and Competition: Evidence from Real Estate Development, National Bureau of Economic Research Working Paper, no. 12486.

Copeland T., Antikarov V., 2001, Real Options: a Practitioner's Guide, Texere, New York.

Kyungwon K., 2008, Real Options: A Way to Deal with Market Uncertainty in Real Estate Development Projects, Massachusetts Institute of Technology, Cambridge.

Neufville R., de Scholtes S., Wang T., 2006, Real Options by Spreadsheet: Parking Garage Case Example, Journal of Infrastructure Systems, vol. 12, no. 3, p. 107-111.

Wiśniewski T., 2006, Koncepcja wyceny opcji rzeczywistych metoda symulacji Monte Carlo, Prace Naukowe Akademii Ekonomicznej we Wrocławiu „Zarządzanie finansami firm - teoria i praktyka”, no. 1109 , p. 694-703.

Wiśniewski T., 2005, Symulacyjna metoda wyceny wieloczynnikowych opcji rzeczywistych, Prace Naukowe Akademii Ekonomicznej we Wrocławiu „Inwestycje finansowe i ubezpieczenia - tendencje światowe a polski rynek", vol. 2, no. 1088, p. 357-367. 